Katarzyna Waniek (1)

University of Lodz, Poland

\title{
The Precarious Life Situation Trap. The Case of "Zealous" Julia-A Proponent and a Victim of Neoliberal Reality
}

DOI: http://dx.doi.org/10.18778/1733-8077.15.4.08

Abstract The analysis of Julia's (b. 1984) case, empirically grounded in the autobiographical narrative interview method, will discuss the mutual influence of the individual experiences and the collective processes that result in a precarious life situation being a stage of the trajectory of suffering process. It will be argued that the generation born between 1980-1990 that entered their adolescence period (and, at the same time, labor market) in a very specific socio-cultural context, framed by the dynamics of interrelated processes of political transformation, vibrant modernization, globalization, and, last but not least, development of neoliberal ideology, has been the first one in Poland to be exposed to the deep and overwhelming biographical changes. They have been oftentimes connected with the feeling of biographical trap and the experience of precarious balance of everyday life that-to a large extent-is a consequence of belonging to intensively multiplying social words with their divergent stocks of knowledge at hand, clashing ideologies, conflicting moral standards, dissonant rules of conducts, and expectations. Additionally, in the discussed case I will deal with a biographical irony: Julia is both-a zealous propagator of allegedly universal attitudes of neoliberalism and a victim of this subtle mode of power. All these contradictions and tensions are clearly seen in the formal features of her (as well as many other people born in the 80's last century) renderings, which are nonlinear, incoherent, emotionally overloaded, and full of fading-out phenomena.

Keywords Biographical Trap; Trajectory ofSuffering;Political Transformation;Precarious Balance; Autobiographica Narrative Interview

Katarzyna Waniek is an Assistant Professor at the Department of Sociology of Culture, Institute of Sociology, Faculty of Economics and Sociology, University of Lodz Poland, and was a Research Assistant in the EU FP7 "EUROIDENTITIES" project and a co-worker in a project "Experience of the Process of Transformation in Poland. Sociological Comparative Analysis Based on Biographical Perspective" financed by the NCN program. She gained the title of Doctor of Philosophy at Otto-von-Guericke Universität, Magdeburg For many years she has been conducting and analyzing autobiographical narrative interviews. Her research interests include: biographical methods, European identity, collective memory, immigration and intercultural communication, liaison work, transformation, suffering, and stigmatization.

email address: katarzyna.waniek@uni.lodz.p
$\mathrm{U}$ sually taken for granted "typologies" of contemporary Poles (for example, these related to the distinction into transformation "winners" and "losers") in their simplified version do not really reflect extremely complex, multi-layered, and ambiguous biographical processes and their feedback to social processes, although they have a real impact on social policies and media ways of explaining social reality.

A meticulous and rigorous analysis of narrative interviews gathered as part of the project "Experience of the Process of Transformation in Poland. Sociological Comparative Analysis Based on Biographical Perspective ${ }^{1 \prime \prime}$ basically verified this binary, schematic image and allowed to capture paradoxes, tensions, ambivalences, and biographical traps, which often result from a more or less conscious inability to deal with the expectations which contemporary people face through numerous and diverse social worlds and inabilities to meet the requirements mainly articulated in the form of ubiquitous discourse of agency and self-responsibility. Clearly, the assumptions of the project take into account that it is not without significance in which phase of the individual's life course the process of moving from the discourse legitimizing the oppressiveness of the socialist social formation to the language promoting the attributes of the neoliberal subject took place. The case analyzed in the text below is an improvised autobiographical account of Julia, ${ }^{2}$ who was born in

The project "Experience of the Process of Transformation in Poland. Sociological Comparative Analysis Based on Biographical Perspective," financed by the NCN program OPUS V UMO2013/09 / B / HS6 / 03100), was implemented in 2014-2017 by the Department of Sociology of Culture at the University of Lodz. Most of the names in the text are fictitious.
1984 in Nałęczów as the penultimate of five of her parents' children. She graduated from the faculty of political science and sociology in Warsaw; she is currently a doctor of political science operating in the coaching and training industry. Thus, she belongs to the generation, colloquially understood as the one which grew up after 1989 and which is said to have their entire conscious life fully in conditions of freedom, which allegedly makes them the first full beneficiaries of systemic and political changes in Poland. This harmful, simplified, and thus falsifying the reality thesis will be subjected to criticism here in the light of an individual (but compared to other cases) life history. What is more, attention will be paid to the chaos of orientation typical of contemporary complex societies which results from "the dissonant concert of social worlds" (Schütze 2002:75) and irritation caused by the inability to see one's own life as a whole (Schütze 2002:75), which, most probably, was the first time fully experienced in Poland by people belonging to the cohort born in the eighties of the last century.

Many of the general features of Julia's biography, ways of experiencing events in life and their social framework can be found in the autobiographical narrative interviews of Hanna (medical doctor) and Inga (visual artist) discussed elsewhere (Waniek 2016a). ${ }^{3}$ Among the most important ones is the fact the narrators belong to the cohort of people born in the first half of the eighties of the last century, whose process of adolescence and entering into early adulthood (and thus the labor market) took place in the context of dynamic and interrelated processes

${ }^{3}$ All interviews were conducted by Joanna Wygnańska. 
of political transformation, entry into the structures of the European Union, intensive modernization, globalization, et cetera, ${ }^{4}$ while the parents were absent-absorbed with work, grandmothers took care of the narrators, all of them have siblings, all of them were good students, active volunteers, and all of them got higher education. None of them has children, though Julia-married as the only one of them-thinks very seriously about motherhood. However, if the cases of Hanna and Inga (in a certain simplification and with caution in adapting Bourdieu's statements to Polish reality) can be considered as examples of parents' social position reproduction (Bourdieu and Passeron 1977; Bourdieu 1986) in the conditions of a vividly changing political and social framework, then Julia's case shows a strong orientation on improving social position thanks to the education and the possibility structures offered by a capitalist market economy. In contrast to both narrators, Julia does not come from a bourgeois-intellectual family, and spent her childhood and early youth in a small town. Thus, the life history analyzed here will be another (contrasting) theoretical variation of the biographical entanglement in neoliberal reality giving an illusory sense of freedom and control over one's own life, while in fact it only blots increasing disorder, anomie, and self-alienation (Riemann and Schütze 1991;

${ }^{4}$ It should be added that in the project mentioned above interviews with people born in the years 1960-1970, 1970-1980, 1980-1989 were carried out. The latter group-analyzed in this article-is distinguished by two features: the first is "the process of socialization within an educational career," ed to the socialist era but at the same time was not strongy rooted in project thinking, creativity, or expectations of multifaceted development. The second feature is: the weakening sense of "stability of occupational career, clear rules on the labor market."
Schütze 2012). ${ }^{5}$ Julia goes a step further, unlike Hanna or Inga, who are subordinated to the expectations of the new capitalist order in their professional activities. Convinced of the necessity and importance of "project me"-self (Bröckling 2016:189 191), she becomes an expert who actively promotes and implements this order, a coach supporting the adaptation of individuals to free market realities or an instructor "producing compliant subjects" (Foucault 2008:178). In the canon of values regulating her daily experience in both the sphere of work and private life, we find among others: the need to invest in development, monitoring, and rigorous implementation of her own life plans, being flexible and resourceful, being immune to constant changes and difficult situations, as well as being rational. However, the point is that-as the text below is mean to prove-a significant part of these values constitutes, so to speak, the biographical equipment of the narrator, perfectly embedding into "governmentality," ${ }^{\prime \prime}$ while the basic rule of this situation, the rule of self-confidence, creating (often illusory) self-image and selling (even apparent) skills on the free market can hardly be implemented by her. A detailed analysis of Julia's life course also reveals a systematic contradiction visible in the fact that she is a zealous propagator of allegedly universal attributes of neoliberalism-including the supreme idea of "entrepreneur of the self" (cf. Foucault 2008; Stachowiak

5 Other cases approaching the maximum contrast can be read about in the articles by Jacek Burski (2016) and Joann (2016).

"Governmentality" is understood as a "neoliberal variant of explains after Nicolas Rose (1998; 1999), "is oriented to governing through freedom"-managing the actions of entitie convinced about their autonomy, independence, and self-determination" (see also Czyżewski 2009a).
2013:141-161; Bröckling 2016:20-40), and, at the same time, she becomes a victim of this subtle and imperceptible form of power. This antagonism within her life history, which the narrator is not aware of, leads to many tensions, a sense of confusion, and a significant limitation (or suspension) of biographical work. In this aspect, Julia's biography reveals many features typical of a modern complex society that are a consequence of entanglement of individuals into numerous social worlds. ${ }^{7}$ Not only are these worlds constantly growing (often competing for members), but they become more and more fluid (their borders are blurred) (Schütze 2002). Thus, nowadays people not only have to deal with various (often contradictory) styles, logic of behavior, and moral standards of social worlds to which they belong, but also with the dynamics of internal changes and disputes regarding the authenticity of core activities in each of them. In addition, all of them-requiring specific knowledge resources, creating their own "We"-cul-

Adele Clarke (1991:131) defies social words as "groups wit shared commitments to certain activities, sharing resources ideologies about how to go about their business." Any social world is characterized by communication and activity (Strauss 1978; 1982) and it is based on common experience, mutual interest, shared symbolizations, shared perspectives on "reality," and, what follows, constitutes its own universe of discourse. It neither has its formal boundaries nor is connected with formal membership and authority relations among participants, but is bounded "by the limits of effective comes that: "Through extended communication, participants in social worlds characteristically generate, or adapt ideologies about how their work should be done and debate about both their own activities and other's actions that may affect them." As Fritz Schütze (2002) emphasizes, social worlds are in their creation, organization, and change immensely flexble. Therefore, the social world is either a national or religious community, a political party, a non-governmental orconnoisseurs, postage stamp collectors, subscribers to certain YouTube channels, football fans, vegetarians, anti-vaccine supporters, Polish immigrants in England, advocates of alternative medicine, protagonists of specific psychiatric therapies, et cetera. ture and awareness (Schütze 2002:63) - create a sense of moral commitment to achieve common goals and oblige to loyalty. It seems that this process intensifies significantly among people born in the eighties of the last century, ${ }^{8}$ in the life histories dominated by the sense of confusion, tension, disorientation, and irritation caused by the cacophony of logic, moral orientations, standards and ways of organizing work, criteria for assessing undertaken actions, ideologies, values or obligations characteristic of different social worlds (cf. Clarke 1991; Strauss 1993; Schütze 2002).

Actually, Julia's story shows growing uncertainty and confusion resulting from the overwhelming arrangement of various social worlds, where participation, it should be noted, is the consequence of either institutional expectation patterns (e.g., various only money-making job worlds), biographical action plans (e.g., the social world of academy, non-governmental organizations, the world of trainers and coaches), and the trajectory of suffering (e.g., the social world of medicine). It can also be said that an increasingly intense feeling accompanying the narrator of being pushed as a consequence of both precarian and precarious life situation (Szarfenberg 2016), resulting from the special configuration of her own and her husband's trajectory of illness (Riemann and Schütze 1991; Schütze 2012) and unstable, multi-format employment, forms. Thus, her autobiographical account is not a story about the path to success, but about continuous efforts to maintain the state of

${ }^{8}$ It does not mean that such phenomena did not occur before, but only that the autobiographical narrative interviews collected in the autobiographical research projects show that in the years 1980-1990 there was a significant change in both the content and the form of the story. 
unstable equilibrium (Riemann and Schütze 1991; Schütze 2012), controlling (often excluding) logic and moral standards of different social worlds, and attempts to remain (at least to a minimal extent) loyal to each of them, as well as the constant necessity to suspend her own biographical plans, which require huge amounts of physical and emotional work, and bring the potential of an unexpected breakdown of everyday life organization (Riemann and Schütze 1991; Schütze 2012)

\section{Shortly on the Socio-Political Frame of Julia's Experiences}

Before we analyze the life history of Julia more thoroughly, let me outline the social, political, and cultural framework of her biographical experience. These, as Fritz Schütze (2008a; 2008b) argues, influence and sometimes even condition the course of the biographer's experience and, in turn, are shaped by the biographer.

A lot has been said and written about systemic transformation in Poland, examining it mainly from the macro level and subjecting it to analysis in the theoretical-methodological frame of the normative paradigm. ${ }^{9}$ The description categories and definitions related to the process of changing the political order for which 1989 was agreed as a breakthrough date (although this issue is also debatable) were often uncritically and carelessly accepted and included in public discourse, and thus in social awareness. Initially, as Andrzej Piotrowski (1997:329) shows, a specific "hope-based pattern of thinking" prevailed, carrying the message that systemic transformation as "the abolition of anti-order brings order in itself, because it simply restores it." The image of order was imported from the West often uncritically and unreflectively, that is, with no regard to political, historical, and cultural differences, or symbolic constructs of collective identity (Piotrowski 1997:328). It was based on the often illusory conviction promoted in all the countries of the Soviet bloc after its collapse, that the free market economy guarantees success to all undertakings basing on its rights. In the public discourse, the systemic transformation was presented primarily as a collective process of change associated with the emergence of new creative possibilities, and with unveiling previously stifled potentials of own initiative and entrepreneurship. Certainly, for many people the sequences of events in life were of such kind, but for dozens of them that period was associated with the experience of disorder and suffering. As shown by numerous empirical data in the form of autobiographical narrative interviews ${ }_{1}^{10}$ individual biographical processes interweaving in different configurations, and with different strength of experiences of political, social, and cultural reality at that time, often led to a sense of disorder-chaos of values, interpretation schemes, or orientation systems. For dozens of people it was-if you recall Émile Durkheim's (cf. 1952) reflections on anomic suicides-the crisis situation understood as distur-

${ }^{10}$ Apart from the OPUS V project, this thesis is also confirmed in the collection of the autobiographical narrative interviews gathered as part of the project The People's Republic of Poland and the German Democratic Republic in Memory and Biographica Experiences of People Born Between 1945-55. Sociologica Polish-German Scientific Foundation (PNFN 2012-03) implemented in 2012-2015 by the Department of Sociology of Culture of the University of Lodz and the Otto-von-Guericke University in Magdeburg, funded by the Polish-German Foundation for Science (cf. Kaźmierska and Schüzze 2013). bance of balance which appears always when there are major changes in society-regardless of whether they are caused by a sudden increase or an unexpected cataclysm. Unexpectedly, the orientation structures changed, the values that had been underestimated or suppressed, such as: own initiative, competitiveness, economic success, or continuous development, became normative rules and constraints organizing social life. As Marek Czyżewski (cf. 2009a:91) showed, "economizing" rhetoric and "economizing" legitimations were triumphing. They spread to all fields of social activity (including family and school) and almost "sanctified" being entrepreneurial, creative, and resilient. The routine methods of conduct known up to that time proved to be unreliable, the horizons of expectations vague, the mechanisms governing the world of everyday life unobvious (they ceased to fulfill their nominal, regulating function). This led to growing and encompassing new areas of social life anomie, which meant chaotic social processes associated with deep cracks in the world of values and expectations, disorientation in everyday life, and weakening of social ties. In sum, this was the period in which a sudden social change shook or seriously destroyed the existing symbolic universum allowing for giving sense to everyday reality and thus outlined the framework conditions for the emergence of collective and individual trajectory processes. A significant role in the transition between such culturally different worlds and languages could be played by symbolic elites (Czyżewski, Kowlaski, and Piotrowski 1997; Czyżewski et al. 2014) by introducing a liaison work open to the perspective of an "ordinary citizen," but they stopped mainly at paternalistic giving instructions and reprimands.

\section{Julia's Life History}

Julia's biographical experiences constitute an extremely interesting case of the collision of expected and propagated (in family pedagogues, curricula, or public discourse) attitudes and life orientations, ${ }^{11}$ which changed dramatically along with the process of political transformation in Poland. As much as for a socialist social formation based on disciplinary power the pattern of an obedient, amenable, diligent, and zealous man was useful in the "marketized" neo-liberal reality and the "governing through freedom" domination, creativity, flexibility, innovation, self-responsibility, and social commitment are required from the empowered individuals (cf. Czyżewski 2012a:118; 2012b:90).12 Therefore (taking into account the previously mentioned cases of Hanna and Inga), we can point to a certain varian of the experience of transformation process characteristic of people who were socialized in communist Poland in the eighties of the last century, their early educational career took place in an experimental attempt of education reform according to the western model, early youth fell in the period of Poland's

${ }^{11}$ Referring to the method of autobiographical narrative intercedural requirements of institutional expectation patterns (ct. Schütze 1981; 1984).

${ }^{12}$ Moreover, Marek Czyżewski (2012a:118) emphasizes that in a rapid problematization of identity takes place and their funa rapid problematization of identity takes place and their fun the term "identity," which appears only in this syndrome, is often used in scientific discourses (including sociology of identity"), journalistic and political; in the social sense, the narcissistic focus on one's own identity may be accompanied, on the one hand, by the fear of permanent identity and, on the other
hand, by the sense of the disappearance of identity; the liberation of identity from the obvious, imposed realms and the flexible outline of the preferred identities paradoxically lead to the formation of a limited set of "licensed" identities ("a creative worker," "an active citizen," "a responsible parent"). 
entry into the European Union and the promotion of various forms of civic activity, and the time of entering the labor market was already dominated by the logic of neoliberal world. The course of Julia's life history is distinguished by-leading to increasing trajectory potential- disharmony between the zeal gained while in family home and lack of self-confidence: the tension between faith in reliable knowledge and the requirements of the external world in which creation of illusion, dramatization of own actions, and creating one's own image counts (Goffman 1990). However, the paradox in this case is that being a member of the social world (Strauss 1982; 1984; 1993; Clarke 1991) of trainers and coaches working in favor of "molding and producing compliant subjects" (Stachowiak 2013:142) desired in the "knowledge economy" and propagating allegedly inalienable abilities ${ }^{13}$ she began to notice the game of appearances in this area, but not so much in the key activities and ideologies of this world as in executive technologies (Strauss 1993:212). I will return to this issue later.

The interview with Julia took place just before her thirtieth birthday, which the narrator says herself at the beginning of the forty-nine page transcription. ${ }^{14}$ She states that she has earlier talked to her husband, Andrzej, about taking part in this research and, as she says, she told him: Well, OK, we will close a certain

When explaining the concept of coaching, Tomasz Bogotębsk the collaboration and cooperation model-a way to extract their potential from individuals in order to maximize profits (understood broadly and without limiting them-explicitonly to the financial perspective)."

${ }^{14}$ The entire translation includes fifty-one pages. It means that the first part of the interview based on a spontaneous autobiographical narration was extremely long. period of life..$^{15}$ This is an atypical situation of starting an autobiographical narration in a double meaning First of all, we deal here not so much with the "standard" preamble, in which the narrator usually tries to describe-yet not entirely clearly, even for himself or herself-the general global form of his or her own biography, as with a kind of metacommentary concerning the summary "function" of this event for-and this is the second extraordinary elementtheir (i.e., Julia and her husband's) previous life. On the basis of the form of this preliminary statement we can conclude that, to a large extent, the course of her life has been shaped together with or in relation to Andrzej, and that undoubtedly he is the key figure of the drama (dramatis personae) (Schütze 2008a:173-174; 182), an important event carrier and the significant Other in the sense of George Herbert Mead (1934).

Julia's childhood memories revolve mainly around her father's alcohol problems, which most likely led to the fact that shortly after her birth he los his job as a construction manager and looked after his little daughter (which, in her opinion, resulted in a much stronger bond between them later in life). ${ }^{16}$ At that time, the mother became the main supporter of the family. Three or four years late her father left for France, where his family lived, to

${ }^{15}$ All statements of the narrator are in italics, symbols introduced in the text mean respectively. (.) short pause, / unfirditional nonverbal reactions of the narrator such as laughter or of a narrator's or researcher's speech, [] square brackets con-

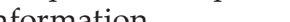

biographical meaning or in situations requiring episodes of narrator speaks of parents in general terms, and in a while the mother appears to be as an interaction partner, a commenter, or a supporter. look for a job there. The goods brought from there "shaped" the image of the West she had; by the way, atypical for many people whose childhood fell in the late eighties and the early nineties of the last century ${ }^{17}$-as the land of "milk and honey." Julia recalls the return of her father from France: I saw them for the first time in my life, Mars bars, Bounty bars, such tiny ones in the boxes and French cheese (...) And then she mentions three colorful school backpacks, and how her father talked about huge areas with shops where you just walk around and you look at them, yes. And there were so many of them and everything was so colorful and you could buy whatever you wanted [laughing]. A counterbalance to the colorful world of all sorts of easily available goods (of course, those important for the child) was the image of the PRL ${ }^{18}$ queues "to everything," in which Julia as a child had only one task to stand in a line and look at the shop assistants with big eyes, take the goods, and come back to the queue again (laughing). This experience of contrast between the sad reality of the real socialist economy and the colorful world of capitalist prosperity may have had its repercussions on the image the majority of contemporary Polish society had of the "betterness" of the Western world and the unproblematic, thoughtless acceptance of its patterns.

The grandmother helped in maintaining the house and taking care of the children when the "busy" parents were not at home. This is another common

${ }^{17}$ Hanna, for example, describes her first trip to her uncle in Denmark in 1993 as a clash with prosperity, with chips and candy walls (Waniek 2016a:134).

${ }^{18}$ The Peoples' Republic of Poland: the post-war Polish republic existing till 1989, economically and politically dependent on the Soviet Union. denominator in the accounts of Julia, Hanna, and Inga.

Actually, my grandma brought me and my older sisters up (...). My mum was at work all the time, my father was at work all the time as well. And, to tell you the truth, my childhood/ I've got vivid memories (.) only of having teas with my grandma. I came back from school, had dinner (.) and then at 5, at 5 o'clock I used to come to my granny for tea. She put a lot of sugar into my tea and she used a lot of lemon, so the tea made by herl I've never managed to prepare such tea.

An extremely strong and emotional relationship with her grandmother and elderly people in her family is evidenced by the passage in which the narrator talks about the traumatic period in her life related to primary school (further on) and says:

when I look at my life now, the most, the most important was eee the most the most (.) the most difficult time was the time of primary school between '95-'96 when my grandma died. Ymm my grandpa died. And five months later my grandma died and five months later my uncle died. He was the only man with whom I had close relations. And the loss of these three people made my relations with people weren't so deep any longer (.) Actually, I stopped mourning my grandma (.) oh, wait, I think I haven't yet. And I stopped mourning my uncle last year. And it's strange that their deaths affected the whole family, because it was, you know, like a set (she snaps her fingers), wasn't it? When you get/ the only granddad, the only grandma who raised us all and the uncle who was a part of our family.

It should also be mentioned that at that time Julia's parents were building a house for which, as she 
explains, they didn't get a loan for the house, but they had to build the house with the money they had earned. They didn't have time for their children. And later they had to earn money for every renovation of the house. In spite of significantly different political and economic conditions, Julia always tried to keep to the principle that all goods should be bought with the savings, not the money borrowed from the bank. Let me note that the narrator does not problematize, firstly, that obtaining credit in the period of the PRL in the form in which it is presently possible was unrealistic and, secondly, that the work involved parents to such an extent that they didn't have time for their children.

The first issue-especially in the light of later narrator's decisions-seems particularly interesting as it is the proof that (leaving aside any assessment) a certain fixed pattern of acting and understanding how the economy works did not undergo profound changes, as the symbolic elites of political system transformation wished for. Let me add that this is just one of several areas in Julia's experience in which she almost "stiffly" refers to principles internalized in the family which order the world, when she has to face the contemporary free-market reality and the pressure of capitalist rationality.

Let me look at the way the narrator talks about her primary school experience and extremely difficult relations with his peer group, which contributed to the sense of inferiority, lack of recognition, and a sense of isolation. She talks about this period: and primary school is not easy when you are a good student. I remember I didn't have many friends. This theoretical-argumentative commentary is often repeated by her as the explanation of lack of sympathy among classmates and reproduces the simple condition that being considered "nerdy" is associated with lack of acceptance among peers. But, when the narrator mentions enigmatically, in the fifth grade, when there werel there were strange relations between the girls in my class, she adds: some of them laughed at other people's clothes, that they are poorer which eventually cost her a nervous breakdown, this suggests another, though not yet under reflection, account of the existing state of affairs. In other words, Julia sees, but does not notice (or does not want to notice) (Garfinkel 2002), other or additional reasons for being disliked and postponed. However, looking at her biography as a whole and applying the procedure of pragmatic refraction, ${ }^{19}$ we can, at least partially, uncover these imperceptible conditions. We already know that the family was large, the mother worked "in the budgets," Julia's father struggled with an alcohol problem, which probably (as the narrator admits herself) was the reason for his dismissal, ${ }^{20}$ he had a tendency to give money away; and when Julia was born, the family moved to a newly built, but not fully finished, house. Undoubtedly, all this contributed to the significant impoverishment of the family. Julia shows her parents as extremely economical, who didn't spend money on rubbish and the children wore clothes one after another, but perhaps they were just

${ }^{19}$ Mieczysław Marciniak (2016:192) writes: "It means the necessity of analytical binding these formally separate unit of expression with those reproduced on the basis of 'proper narration' with biographical processes. This allows us to unpenetrate what is consciously and unconsciously obscured by the narrator which created deeper sources of tension in the biography-and thus makes it easier to penetrate into the biographical process."

${ }^{20}$ Julia explains that her father, as a plumber-installer, was working on the construction site at that time and the construction sector in Poland was strongly allied with alcohol. poor at that time. ${ }^{21}$ In this perspective, we should look at Julia's relationship further, in which her desire to be recognized and accepted was devastated in a dramatic way. It is reflected in the analytically significant linguistic phenomena that interrupt the flow of narration-the background construction. ${ }^{22}$ It contains a story about her tenth birthday party, at which none of the invited guests showed up. This distant-in-time event has an unusual emotional charge-recalling it during the interview, the narrator begins to cry ${ }^{23}$

I remember, I still remember (.) When I was in the fourth grade of primary school, my mum let me have a birthday party. (...) And it was the first time I could invite my friends to the party. (.) But, it is such a strong memory, be-

One more detail from her childhood may speak in favor of it: And what else I remember from the free-market economy are crisps. My friend could afford buying crisps. And she bought a packet every day and she shared with me. (she laughs) These were Star Chips, Starbacks (.) no, not Star Chips, just crisps, yeah, that's right.
Pizza and cheese flavored. And she could afford buying them. And she bought crisps and she shared with me. I envied her so much. She might afford it' as I've told you, there were four kids in my family and we didn't have such a possibility. You remember such strange things. Today I'd never buy these crisps (with a smile)[...] But, I remember that Magda [Julia's friend] could always afford buying these crisps and it was amazing for me. I thought she was so extra rich.

A background construction means a sequence introduced ater than the sequence of events in the life would require. It signals that the combination of experiences was either exremely complicated and it was difficult for the narrator to recapitulate it in a linear order, or too painful or shameful and, of narrative constraints forces him/her to go back even to emotionally difficult experiences, to give sense and authenticity to his/her biography in the eyes of the listening researcher. The latter option is called a fading-out phenomena. In this passage, we deal with a background construction which takes the form of a documentary (Belegerzählung), which is to justify the narrator's claim that she remembers every purchase of a new thing (cf.
Schütze 1983). In order to do this, the narrator must go back in the chronology of the presented experiences and recall the traumatic event related to the purchase of shoes that she originally wanted to neglect.

${ }^{23}$ Apart from crying detailed recapitulation, accumulation of pauses, and finally the reconstruction of internal dialogue are the formal markers of the significance of the mentioned event for the overall Gestalt of her biography (cf. Schütze 2008a:2006-2008) cause (.) nobody came (she cries). Mum took me in a carl (.) we were waiting in front of the school. Nobody came to my party. (...) (she cries) And mum went with me to buy shoes for me and I remember till today what the shoes looked like. (.) But, it is such a memory which, you see, which hurts even today. (.) But, it was a bit like this: it was the fourth grade, I was a good student, so nobody liked me. It was clear and obvious. I was able to say to myself: OK, I can't help it (.) I've got my first new shoes then. They were bought in a very exclusive shop in a sense, you know, it was a shoe shop opposite my primary school. So, I said it was exclusive, because it was. I guess it was in '96. Yeah, it should be? My fourth grade, '95-'96, more or less. And I remember this feeling: "new shoes," well, you know (.) later I/ You know. I don't have nice memories from primary school. No warm feelings. It was a normal, mainstream school, where you got rejected if you were a good student. You just got rejected. And I couldn't share it at home, imagine what could I say?-that my friends didn't like me?

Let me concentrate on what happened then (her friends did not come to her birthday party, she was disliked by them), the narrator again explains it referring to the common sense rule: I was a good student, so nobody liked me. However, we should ask once again if this is the only possible explanation of this situation and whether there were any other reasons for which the classmates disliked Julia. The most likely seems to be, as I have already mentioned above, the negative image of her family in the local community. We can deal here with "the tendency of stigma to spread" (Goffman 1986:30-31); a situation in which people avoid relationships or completely break up not only with stigma bearers (the parents), but also people from their closest surroundings (Julia) (Goffman 1986:30-31). However, we can only 
speculate whether this stigma was related only to poverty, alcoholism, or other factors. Another intriguing issue in the above quotation is how her mother compensates Julia for what had happened. She did not make any attempt to explain this difficult situation of humiliation to her daughter, nor did she suggest how to deal with it emotionally, but she bought her the first new pair of shoes in her life. It will later become Julia's only acceptable form of justifying spending money on new things: a kind of substantive compensation for moral and emotional losses (buying a flat, for example, would be a reward for the hardships of writing a PhD).

However, coming back to the school period: Julia was in the sports class (according to a quite controversial idea of gathering the best students in it) and she suffered constant failures in this field, which was associated with the incessant experience of humiliation, degradation, and exclusion: I was terribly bad and nobody wanted to play with me. They didn't choose me to their teams, and, you know, I couldn't catch the ball at all. (...) Of course, I didn't take part in any competitions, you know, because in general I was hopeless. She also took part in the mathematical group meetings (and, once more, she gets there-as a result of the "experimental" educational policy of the early nineties-as a person who cannot cope with mathematics). Here again she was the worst one, but later she did very well in the competence test. Initially, these poignant feelings were reinforced by experience at the music school, to which parents sent her when their financial situation stabilized (it was around 1993). The first piano teacher was so horrible that Julia had nightmares and her sense of inferiority increased by being repeated constantly that she was stupid and hopeless. ${ }^{24}$ Fortunately, the next music teacher turned out to be nice, thanks to which the narrator stayed in this school. Today she is convinced that attending the music school allowed her to gain specific skills such as, for example, the ability to share your attention, to share concentration between things, to do many things simultaneously and general development in these classes that caused the stimulation of her brain. It is worth asking a question here: if she were not a diligent, hard-working person, with divided attention and managing her time skillfully would she be able to complete the music school? Julia is convinced that the acquired (or rather improved) competences constituted her present knowledge, which-let me add-can be used to train people in neoliberal virtues such as: entrepreneurship self-discipline, creativity, innovation, responsibility, or personal development.

The sequence of events in Julia's life brings us to the seventh grade of elementary school and, let me say, the epicenter of the maturation process. At that time the narrator found a soul mate-a friend with whom she created a tandem as she recalls it: We were mean bitches (...). Everyone was afraid of us. And we did what we wanted, you know. I was very much concerned with what others thought of me. But, since they thought bad, I stopped being interested in their opinion. I just did what I did. It becomes clear to us that the main youthful concern of Julia (mitigated slightly only later) was

${ }^{24}$ And she adds: but, damn it, I've learnt to play the piano. I've learnt it to her anger (.) I've really learnt. (.) And I was pretty good excerpt is noteworthy because of the specific formal feature of Julia's story: whenever, due to the narrative dynamics, the natrator re-experiences situations of humiliation and helplessness or extreme competence uncertainty, her language becomes vulgar. her image in the eyes of others and the fear of failed performances (Goffman 1955; 1990; Riesman 1989; Gergen 2000), so becoming adolescent (as most teenagers) she decided to take a rebellious attitude, different from the role of a polite, good student assigned to her so far. Her new identity was first manifested in a vulgar judgmental commentary (we were mean bitches) and then with regard to more and more arrogant or aggressive actions which can be detected in the hints given by her interactive partners (Everyone was afraid of us). It was also a period when Julia's situation in terms of establishing relationships with people began to change significantly: she joined the school's self-government (teachers appreciated her communication skills), prepared discos, fundraising, and she was engaged in voluntary work. All the time she concocted and organized something, because-as she emphasizes-I liked doing something, I liked when something was going on around. She took part in the competitions in Polish language, history, but also in physics-she never won any of them. As she comments now she had some successes in science: didn't prevent me from choosing a class of humanistic profile.

And that is how Julia went to high school, which she comments: it was one of the most amazing periods in my life where she met people who wanted to develop, people who appreciated intelligence. People who had crazy ideas, and they realized them. It seems that she finally found a group of friendly people with whom she shared interest in rock music and liked (with mutuality) to spend her free time with. She became a member of the social world which was based on the sphere of her authentic inner spontaneity (Schütze 1984). It was only then that her desire "for securing a recog- nized, enviable, and advantageous social position (Thomas 1969:31) was fulfilled. She still went to music school ${ }^{25}$ and she was active in volunteering, where she looked after elderly people. Since she was seventeen she spent weekends, holidays, and days off working at a guest house (she found this job herself). She was constantly busy. She was only worried about insufficient knowledge of English, which she realized during the competition organized for high school students from European Union candidate countries. She persuaded her parents to provide her with a very expensive English course. ${ }^{26}$ As the narrator claims, education was the only thing on which my parents didn't skimp money. It is worth stopping here to pay attention to parental pedagogy, which was based on systematic message that education guarantees work, allows for achieving a certain and permanent social position, and thus guarantees stability in life. In its clues and instructions, this message was to prepare for middle-class life. That is why they supported their children financially, even if it was with a considerable effort. This theme repeats throughout Julia's story, starting from elementary school, when she explains that: I was quite a good student, because my parents used to repeat education was important. That if I studied hard, I'd get/ I'd get a good job. And I believed this illusion [laughing]; till the time she completed doctoral studies (which we will look at further). Let me take a look at one more principle Julia learned in her family home and, what's important, the principle she mentions talking about

${ }^{25}$ Julia graduated from the second degree of music school, to studying and working ine $30 \mathrm{~km}$. What is more, while commuted to studying and working in Warsaw, she regular
her hometown, where she sang in the choir.

${ }^{26}$ Most probably it concerns widely advertised on the Polish market at the turn of the century sets (books and CDs) for home language learning. 
the events of her teenage life: In general, yyy my parents taught me one more thing, namely (.) what you do actually depends on you. And it was/ eee they trusted me a lot. This principle has, however, a hidden implication (common with the rules of "governing through freedom"): it involves taking almost complete responsibility for one's own actions, or at least carries a sense of such necessity. Returning to the period of Julia's high school, we must mention two important issues that affected her whole life. Firstly, she went through difficult experience with her boyfriend, future husband-Andrzej, who suffered from eating disorders, was emotionally unstable, and had suicide attempts. These problems were later subjected to therapy, but they still have influence on their life. Secondly, she was diagnosed with diabetes, for which she mainly blames stress related to the complicated relationship with Andrzej and extreme fatigue (she was still in a music school, worked in a guest house, volunteered, organized school events and trips). Her attitude of that time towards the disease is expressed by the following statement: fuck you, diabetes, I'm going to live my way anyway. I mean, I'm going to do thousands of things, I'm going to be active, and I'll show you I can. As we can see, Julia expected a kind of disorder in everyday life (Riemann and Schütze 1991:342), which, however, she did not intend to give in. Most probably, it was related to an attempt to trivialize or fade out the destroying trajectory potential (Riemann and Schütze 1991:349), which increases the feeling of losing control over one's own life and intensifies the threat of exclusion from the normal world of everyday existence (Schütze 2012:420). The above statement can be read as an attempt to preserve the narrator's active attitude towards her own life and identity, but the vulgarity of language she introduced (fuck you, diabetes) seems to reveal the trajectory of suffering Vulgarity of the narrator's statements-which I have already noticed-always appears when the recapit ulated memories "draw her back to the orientational principles and the emotional mood" (cf. Riemann and Schütze 1991:342) related to the irritating sense of helplessness and irritability as a result of deepening alienation towards herself. ${ }^{27}$ Another empirical evidence for destabilizing trajectory potential of the disease will be obtained by looking at the whole of Julia's biographical experience. Then it turns out that diabetes forced a specific way of organizing ev-

${ }^{27}$ However, a few words of explanation are necessary, because many misunderstandings arose about the trajectory of suffering (Riemann and Schütze 1991; Schütze 2012). It is one of (alon with the institutional expectation pattern, biographical actio scheme, and biographical metamorphosis) process structures (i.e., ways of experiencing events in life), which on the basis about their own lives was distinguished by Fritz Schüze an his colleagues (Schütze 1981; 1983; 1984; 2008a; 2008b; Prawda 1989; Kaźmierska 2016). It is characterized by a sense of loss of control over one's own life, chaos, fear, paralyzing disorientation, and a terrible loss of sense in the face of new overwhelming external circumstances, from which there is no escape. A individual touched by it loses confidence in himself/hersel er existential despair. Being a structural process of growing disorder, the trajectory of suffering is paradoxically usually ordered-phased from the accumulation of trajectory potential, through the inability to act intentionally and conditioned response to external circumstances, attempts to regain contro over one's own life giving a sense of precarious balance, to the total breakdown of self-orientation, to the theoretical and practical going through suffering and its acceptance (cf. Riemann
and Schütze 1991. Schütze 2012). Not all of these stages and not always in this order appear in an individual course of suffering people. Not always events that would be sensitively inclined to be interpreted as a trajectory are experienced in this way and vice versa: sometimes seemingly "normal," trivial biographical episodes or their sequences are treated by the biographer as an overpowering fate. This is because of individual an subjective experience of suffering, which in the narrative interview is given not so much by its name, but primarily in the 2012:180), which very often express "complicated, difficult, subtle socio-biographical experiences only quite indirectly, symptomatically, and incompletely, since the latter might be ambivalent, cognitively or emotionally painful, shameful, or simply incomprehensible" (Schütze 2008a:171). eryday life (especially in terms of meals, quality and regularity) or a hierarchy of importance in a modest student budget: [financially] diabetes killed me, you know. I could spend the money on cigarettes and vodka or insulin. (...) You know, you can either go to a party, to the cinema, or buy insulin. And the stripes. Moreover, whenever the narrator disregarded the constraints imposed by the disease and lost herself in stressful and manifold activities, she ended up in hospital in a rather poor condition. Such a situation took place at the beginning of studies and when she started another commissioned job, this time for a large Stateowned company P-Poland. I will come back to the latter situation later.

To sum up this part of the narrator's life course, I can say that from the family home, school, and out-of-school experiences connected with the need to combine activities in general and music school and other social activities, she mastered the ability to save (to manage money in a rational way), self-management, efficient and effective time organization, and the belief in the necessity of constant self-development and civic engagement. The disease increased her ability in self-discipline, resourcefulness, and resilience, or-last but not least-awareness of the need to bear (biographical) costs and "optimize" the attitude towards herself. At this point, attention should also be paid to seemingly minor details in her statements. Well, regarding the music school, Julia recalls: I was a student who learns, but has no talent, and about her matura ${ }^{28}$ exam (passed in 2003) she says: one more form of an exam, which we were not prepared for, as it was based ${ }^{28}$ The secondary school exit exam in Poland that must be passed in order to apply to a university. on reading texts and understanding them. In fact, these are strong signals related to the narrator's competence uncertainty, lack of self-confidence (evoked and sustained by the teachers), and an error caused by the education reform of that time, which subordinated the education system (in its assumption reflecting objectively the level of education and equalizing students' chances) to the test exams. Leaving aside the assessment of the education system and the direction of its change, we must take into account that Julia passed the matura exam, and then went to university without being fully prepared to read the texts with understanding and I may risk an assumption that she was not prepared to a more abstract way of thinking. Biographical situation of the narrator brings to mind the reflections of $\mathrm{Ba}$ sil Bernstein $(1971 ; 1996)^{29}$ over the developed code and the restricted code and their relationship with the middle class and the working class respectively. And so, while Julia's origin would indicate a certain-conditioned by her parents' origin-form of the restricted code, in the cases of Hanna and Julia, used as a reference here, we would talk about the developed code. The question arises, how do these speech systems determine the way of understanding the complicated contemporary world of life and influence the way the individuals act. We must leave it unanswered here. However, we can question the reasonableness of such a direction of the reform of the education system, because, contrary

${ }^{29}$ As a result of harsh criticism (often emerging from misunderstanding), this concept has been repeatedly modified by Bensten hi, thsell. The categorles thenselves. the restricted tors, have become extremely controversial. However, Bernstein wanted to indicate the sources of failure of students with lower socio-economic status and to show why the school system still favors middle-class children (Bokszański, Piotrowski, and Ziółkowski 1977:107 and on). 
to expectations, it still gives an advantage to middle-class children (cf. also Zahorska 2009).

Let me look from this perspective at the sequence of events in the period when the narrator had to choose her studies. Julia talks about the process of making a decision on choosing the faculty:

I was a member of the [youth] Lublin voivodeship sejmik. And we had trips, workshops, meetings, voluntary work, et cetera. It was a great experience. Political studies graduates were our leaders. And I thought it must have been a cool faculty after which people have such a cool job, running these workshops.

Already at the starting point, the narrator shows that in choosing political science, she primarily took into account the cool way of communication in the form of trainings and workshops, not the substantive content of the university's curriculumshe did not know anything about politics, as she says, she could learn it thanks to her studies. Her choice of $\mathrm{UKSW}^{30}$ reveals also a huge competence uncertainty: I was afraid to take entrance exams to the UW (The University of Warsaw). I thought I was too stupid to go there. It may be a consequence of Julia's social origins-although her mother completed extra-mural studies after the birth of her first child and both she and her husband, which I have signaled repeatedly, supported the education of their children, they certainly lacked the insight in the field of the academy typical for intelligent culture capital (Bourdieu 1986; Zarycki 2009). According to their view (at least partially transmitted on Julia), studying was, first of all, supposed to raise the professional qualifications (translated into life stability and better material situation), and, only secondly, if at all, widen cognitive horizons, provide intellectual and moral development of the individual, teach deep reflection on one's own attitudes, and express a critical opinion on the existing social reality (cf. Czyżewski 2009b; Kaźmierska, Waniek, and Zysiak 2015). The very way of choosing the field of study shows that for Julia much more important was the external form than substantive content, which, as can be presumed, could have its source in a variant of the restricted code. However, political science did not fully meet her expectations, and following her friend's advice after the second year of studies, she decided to apply for sociology. This time, having gained some knowledge in the logic of the university's world, she decided to study at the University of Warsaw, where she was admitted under the condition of making up for two years which meant twenty-seven subjects in a year. At that time, she made a strategically important decision: I'm going to get a scholarship at political studies, and actually learn something at sociological studies. Despite such an aggravating plan of duties, Julia continued to engage in the activities of many youth organizations associated with the idea of developing a democratic state (let me remind that these were the years just before and just after Poland's accession to the European Union) both in her home town and in Warsaw. At the end of high school, for example, she started to train for the association operating at the Nałęczów City Council, as she says: I would say, I absolutely don't know why. And she adds that she prepared the first training at the request of one of the officials: about how to deal with stress. And seven people came to my first training. Among them there were six teachers. So, I had a very demanding group, I'd say. I got a real brainwash at start. But, I managed somehow. Other trainings I ran were about stress, managing oneself in time, because it was, I mean, it was something that fascinated me.

For our further inquiries, two pieces of information from this part of her autobiographical account seem valuable. First of all, that the beginning of her experience in the field of "selling" so-called soft skills took place without any professional preparation, but most probably on the basis of imitations of training in which she had previously participated in and probably in relation to the knowledge acquired thanks to pop-psychological tutorials giving the illusion of being an expert which flooded the market at that time. This is an interesting point, because later Julia clearly stigmatized such attitude, that is, running trainings based on a minimum knowledge and maximum "art of impression management" (Goffman 1990). Secondly, this event was a turning point, in which the narrator became convinced that she could make a confession, which resulted in rebuilding or even creating a sense of personal independence and positive self-identity (Strauss 1969:89-118).

Coming back to studying, it seems that in sociology the narrator could finally spread her wings: she began to cooperate with the scientific group, she was fascinated by qualitative research, she began to participate in scientific projects that later translated into marketing and image strategies of the university, she was delighted with working with the team, which she was training in soft skills, time management, knowledge verification, and at the same time prepared scenarios of focus studies, individual interviews, analyzed the collected quantitative data. She also dealt with trainings of project teams, ran workshops to activate the civic attitude of young people, including the ability to write European projects, and finally she was involved in the Youth Democracy and Self-Government project for a few years. Her understanding of social sciences (political science and sociology) was, as it seems, in line with the dynamics of transformations that Marek Czyżewski follows with concern. He says that contemporary cultural, economic, and political changes are supported by:

A compliant and opportunistic transformation of sociological discourse, which does not focus on a critical analysis of reality, but tries to serve it. In sociology, but also in economics, pedagogy, and many related sciences, there is an avalanche spread of research projects, theoretical considerations, expert recommendations, and directions of education regarding creativity, responsibility, trust, flexibility, innovation, autonomy, and the like. [Czyżewski 2013:16]

Talking about her educational career again, Julia decided to undertake doctoral studies in political science, which she considered humiliating and withdrawing in development, and in her work she intended to combine qualitative sociological research with political science issues. At the same time, she began a two-year work in a research project based on qualitative research. Julia considered the group analysis of the data obtained in it as a big plus, which in a sense combines quality with trainings, research with running workshops. Again, we meet the motive of combining 
or mixing orders (or, in other words, social worlds, intersecting with all the consequences of this process): the teaching method typical of a traditional "dusty" and "old-fashioned" university and "modern" strategies taken from the field of organization and management when the narrator talks about accepting with joy the possibility of running political thought classes as a substitute teacher with students at UKSW:

For me [i.e., a former student] these classes were like this: the seventh page of the eighth text of the thought this and that, you know. So, I said to myself: wait, you've got the whole training workshop at hand. Let's take it and use it in the classes. So, I started group work yyy many types of cases. There was work based on Oxford discussions or debates. And yyy preparing drafts, schemas, fitting various thoughts in schemas. Sometimes we worked on a chosen article and we analyzed it on the basis of political thought. And we did other things, you know, what came to my mind.

Again, we deal not only with-in no way problematized-colonizing of the scientific research language by the language of entrepreneurship and human resource management, but also with admitting uniqueness and priority to certain, in fact transformed, but developed at universities, forms of education such as debates or workshops. However, she states this experience was of great importance: she was convinced that if she could work at the university, and thus fully engage in the world of science, it would have been like a fairytale and her PhD thesis would be much better then.

${ }^{31}$ Julia was ultimately very disappointed with the supervision of her doctorate: initially her doctoral advisor had only
However, it did not happen. Julia, like thousands of doctoral students in Poland, had to work to be able to maintain herself. She carried out commissioned research, conducted various types of trainings, was a research project evaluator at the Warsaw University of Technology, had a small position at the University of Warsaw, in the summer she left for Germany ${ }^{32}$ to work in a career of elderly people, but only in primary school near Warsaw, where she worked for one-third of the full time teacher of social studies, she had an employment contract. In this sense, Julia became the victim of an external structural lack of possibility of full, long-term, and stabilizing employment. In this sense, she suffers from precarity (Standing 2011). Jan Sowa (2010:102) defines it as:

referred to the content of the thesis. Later, in an almost plete thesis, he noticed only the lack of reference to his publications from the nineties. The narrator assesses it this way? on the one hand, it was just funny, but, on the other hand, it was tragic. And embittered, she adds: T have a wild impression that nobody-except a friend who made her language correctionread it. I mean, you know, there are many controversial points. My

${ }^{32}$ The comparison of the money earned at that time with the Julia. She comments on this in the following way: Thanks to the work in Germany I could save some money. When I came back I could buy a computer. It was quite interesting, you know, the difference between how much you could earn in Poland for hard intellectual work, where you really needed a lot of knowledge and experience, and how much you could earn in Germany cleaning floors and making dinners. I it was when I graduated from the UKSW (...) I can't remember exactly, but I think I was in the second year of my PhD studie (...) So this difference shocked me. As for Hanna and Inga, Europe es of cognitive knowledge, interpretation systems, and refeence patterns of the narrator (cf. the concept of the Europea mental space: Schütze and Schröder-Wildhagen 2012; Schütze et al. 2012). A comparison of the high earnings of a physical laborer in Germany and low incomes of a white-collar worke in Poland contributed to re-contesting the career path she had chosen. Luckily, later Julia took part in a conference in Grea to the fact that at the university you just talk about the methodology of how to do science, and you do not actually talk about how you ogy of how to do science, and you do not actually talk about how you
do it. This trip (opening up a chance for potential cooperation) again restored the sense of her efforts in completing her doctorate studies. the state of uncertainty, consistency and stability is the chronic impossibility of predicting the future and constant fear that it will bring only a worsening of the current situation. It is the condition of the fragile and uncertain existence which is experienced by a large part of the world's population, also in the countries of the capitalist center. It concerns people who are temporarily unemployed, living on casual or undeclared employment, employed for short-term contracts, migrating in search of income, working part-time or forced to sign in blanco a notice of termination together with a contract of employment (a practice quite common in large corporations). It means a life full of uncertainty and difficult to plan, a life in which you have to change not only your workplace, but also your profession, and even the best position can be lost from day to day.

This situation-contrary to what the narrator's parents assumed-also affects people, such as Julia, young and of high educational resources (Mrozowicki 2017:42). In the world of work, in which, as Richard Sennett (1998:22) shows, "the traditional career progressing step-by-step through the corridors of one or two institutions is withering" and in which, as he adds: "deployment of a single set of skills through the course of working life is no longer possible" one's biography is organized by the slogan "no long term." This condition, which Adam Mrozowicki (2016) pays special attention to, is surprisingly often normalized, that is, considered obvious and not subject to problematization, or not always consciously rationalized.

Characteristics of work precarisation, dynamics of its course, as well as the way of impacting the whole human life in its essence is extremely often the experience of the trajectory of suffering. It takes the form of a trap set by overwhelming external structural forces. Their impact paralyzes the individual's actions to undertake or implement longterm biographical plans, exhausts its physical and psychological forces, and finally makes it apathetic and unable to engage life energy in any counteracting of cumulative disorder dynamics. In the case of Julia, firstly we deal with the phase of the trajectory of strong attempts to maintain the unstable balance and, secondly, with a vicious circle of interaction of the trajectory resulting from a difficult position on the labor market and her and her husband's chronic illnesses, which significantly worsens her life situation. Let me note the narrator's experience when the only mainstay that gave her a sense of stability, supporting the fragile construction of life (an employment contract in a primary school), was shaken. However, it is necessary to mention that, for Julia, the work at school was a huge organizational effort: first of all, she had to commute twenty kilometers, and, secondly, she had to write it into her busy schedule. At first, she treated this job too idealistically and she collided with a disappointing reality, as many beginner teachers do:

I always had such an ideal because as I was writing a thesis in political science, it turned out that it is really bad to teach social studies and kids knowledge about how the country and the society function, their own role in society is none. And I had such a fixed idea to be a great teacher, and that I would prepare people for being active. And it turned out that I won't, because there's the school curriculum, the head teacher watches me, and I, the kids don't want to do anything. And all my attempts to encourage them to be active, 
maybe not all, many of my attempts to encourage them to be active failed.

Despite the difficulties mentioned above and the initial disappointment, Julia worked as a passionate, loved-by-her-students, and respected by their parents teacher for three years-that is, till the headmaster indiscriminately decided to change her employment contract to a commissioned work contract. In this way, he destroyed her biographical action scheme, ${ }^{33}$ made just after her marriage to Andrzej (which took place a few months earlier), namely, becoming a mother. The narrator herself says: I really needed to plan my life somehow, you know. She felt not only cheated, but also extremely aggrieved. She mentions that just after leaving the headmaster's office she just burst into tears. Again, without her fault, she had to revise the concept of her life and postpone her motherhood for later. Admittedly, Julia's decision coincides with the strategies of Polish women described, for example, by Anna Matysiak (2009), ${ }^{34}$ which in general may be expressed by the formula "job position comes first, and only then a baby"; however, as I have al-

${ }^{33}$ The biographical action scheme (or plan) is one of the way of experiencing events in life in Schütze's concept. It takes its of an individual and takes the form of a long-term plan in which both the goal and the manner of its implementation are of an autonomous nature. This structure is expressed by the systematic and active attitude of an individual to his/her own identity of the " $\mathrm{I}$ " and the world of life (Schütze 1981; 1983; 1984; 2008a; 2008b; Prawda 1989; Kaźmierska 2016).

${ }^{34}$ To determine how much these strategies result from the imposed institutional pattern of expectations, and how much the intentional plan of action or the mutual interactions of both of these process structures a subtle and sophisticated analy-
sis would be required. Ryszard Szarfenberg (2016:11) is right stating that there are many hypotheses that recognize a decrease in fertility of women in precarious work conditions. However, it should not be forgotten that the family planning, so strongly subordinated to the work, was possible when the issues subjected mainly to fate began to be controlled. ready mentioned, an additional aspect must be taken into account while considering the temporary suspension of parenthood by Julia (made by the narrator herself), and that is the trajectory of her (and her husband's) illness intensifying the feeling of uncertainty and anxiety. It is also necessary to mention in this context that since the beginning of studies in Warsaw, after a short episode of renting a flat with friends, until the time of completing the doctorate, Julia lived in a dormitory. Every now and then she shared it with her partner, Andrzej, who, overcoming some obstacles (as we can sup pose, related to his psychological state at that time), eventually graduated from ethnology, and laterbasing on skills springing from his passion and not knowledge-he got a job in a company that sells professional music equipment. In the segment preceding the coda (pre-coda segment), the narrator says about the purchase of a flat (of course, without a bank loan, but thanks to the huge effort of longterm systematic savings supported by loans from family and friends) which stabilized her biographical situation and set her in a positive, optimistic mood typical of a biographical action scheme, here in the form of a "nest building" (see excerpt below). If we make the life course of their acquaintances a reference frame, the decision that ended her and her husband's long-term "wandering" was made relatively late. Julia says: And, you know, all friends of mine already had flats. All of them. It was so depressing, lack of the feeling of safety and comfort, fucking shit. This prolonged the terrible period of living in a dormitory, however, the narrator rationalizes referring to the current situation of many of her colleagues who took credits in the boom (...) and now have credits amounting to 600-800 000. In Euros or in
Swiss francs. First of all, Julia states that they are not jealous of this situation, and secondly, she is glad that Andrzej decided to wait for a while. Eventually, as she emphasizes: We didn't get into debt like idiots. We had our own contribution and we could have some loans on quite good conditions (...) but I've got the feeling of safety, I mean, you know, nobody will take the flat away from me. ${ }^{35}$ This balance, however, has an incomplete or shaky character conditioned by work instability, illness, and, above all, the must of suspending a strong desire to become a mother. Let me look at the narrator's statement:

And, you know, I'm happy that I could buy a flat. It's essential. And here further problems appear concerning having a baby with not being permanently employed. I'm 30, I've got diabetes, and I should have had a baby three years ago. I finally have the place to raise it in. But, I have no physical possibility to do so because I don't have a private business, only a start-up. So, in fact, nobody would pay ZUS $S^{36}$ premiums for me. I'd be happy to pay them by myself, but I can't. According to our law, I may be self-employed, but I'm not sure if I want to do that.

In the light of this statement, it is worth looking at a certain event in Julia's life, which illustrates, as I have already pointed out earlier, the unexpected necessity of undergoing the dynamics of diabetes. It seems it took control of her life, especially when she ceased to look after herself when she had too much work and too many duties. Such a situation happened shortly after Julia had received a job as a trainer at P-Poland:

To some extent they represent anti-consumption attitude and the minimalist lifestyle (Dopierała 2017).

The Polish Social Insurance Institution.
When I started working for P-Poland, at the end of May I felt terribly bad. We had a lot of work. Actually, I worked 12-16 hours a day. And at that time I was finishing writing my PhD thesis, doing three projects, you know, I needed to earn money to pay for the refurbishing of the flat. We had already bought the flat in April. And I had a health break down. I had food poisoning. It destabilized the sugar level and, as a result of this, my kidneys stopped functioning. I realized that after five days. It was a free day so we went to a GP. She said: Don't worry, it's only food poisoning. Take this and that and it will be better. It wasn't, I went to hospital to emergency, they kept me for 6 hours. I had my tests done, et cetera. And the doctor said: Your kidneys aren't working, you have to go to a nephrologist. The next day he let me go home with some medicine. I went home. My mother-in-law is a nurse and when she saw me, she said: Julia, you look bad. It turned out I was all swollen and I weighed eight kilos more. Eight kilos of water. My kidneys stopped working and I was taken to hospital to Lublin. I didn't work. When I didn't work, there was no money. And they didn't pay me for the whole month I mean, they paid me only for two days. And I didn't get a bonus. Because it is granted on the basis of questionnaires results. And I didn't have any questionnaires because I didn't do any trainings. So, I didn't get a bonus as well. I really have nothing against paying ZUS premiums. If somebody would like to employ me on a permanent contract, I would start up a business, because, as I say, if we want to have a baby, we have no other option taking into account the character of my work, the way I function, my diabetes.

This passage shows clearly that-in addition to employment instability and, consequently, income-in her plans to have children, Julia had to take into account many interrelated 
factors, ${ }^{37}$ in particular, the disease that could unexpectedly disorganize her routines of everyday life. It can be assumed that given the current situation, the narrator very cautiously tried to keep a minimum of social and financial security. She took into account all "for" and "against" in a manner typical for implementation of the biographical scheme of action, considered alternative paths and possible biographical consequences. To sum up, the narrator's life is a continuous, often parallel interaction of two process structures: an intentional biographical action scheme and a paralyzing (double) trajectory. Admittedly, the dynamics of suffering had a recessive, receding character, but its destabilizing potential constantly influenced the organization of everyday reality.

Let me repeat once again that the period of Julia's studies and subsequent entry into the labor market fell in the period of a dynamic transition from the socialist social formation to the capitalist free market economy, which is based on principles other than those internalized in the family ordering the world of everyday experience, other life orientation models or other personal patterns (Schütze 2012:440-441, see footnote 22). Although the narrator was familiar with neoliberal values in her thinking, the conviction persisted that, even in work based on communicative skills and interactive work, knowledge is most important, and techniques of presenting yourself and manipulating impressions remain in the background (Goffman 1990). Her convic${ }^{37}$ Let us also pay attention to the fact that in the past grandmothers who were retired or not working professionally could
look after their grandchildren, and today contemporary grandmothers still work, often-to support their children financially. This is the case of Hanna, Inga, and Julia. tion-repeated consistently (rooted in her parents) at many points of the rendering-expressed by the formula: if I learn well, I'll gain knowledge, then I'll get a good job, has been severely verified by the mechanisms of the capitalist economy. At first, Julia did not understand the rule according to which "knowledge," in her opinion, still insufficient, can be sold. An idea suggested by a friend to earn on trainings is commented as follows: I always thought I didn't know enough. I still had to learn, I had to (...). And he showed me I didn't. People take money even if they can't do something, they just devote their time, so they work. This excerpt shows not only other "recognition" rules that exist in the field of trainings and projects, but, once again, Julia's enormous competence uncertainty. The narrator talks about this issue again in the coda ending her biographical recapitulation (I will return to it in a while), which shows the importance of this problem in her life and her personal identity. Analyzing the principles of the contemporary Polish labor market in the theoretical commentary, she reveals that: it favors not so much those who have knowledge (but who are also aware of its shortage) as those of great confidence. As she says: unaware incompetence is worth much more than aware incompetence (see also the excerpt of the coda cited below). On the other hand the promotion of attitudes and skills required by the capitalist free market economy gave Julia great satisfaction, especially when-as in the passage quoted below regarding the trainings for P-Poland-she felt that as an "engineer of souls" she put someone's life on the right track:

But, the work is amazing. I work with people from the toolroom, people from the roundhouse. With people who have never had any trainings, never. At my last training a man with 35 years of working experience in telecommunications came and he said with tears in his eyes: Julka, I've been working here for 35 years now, and it's the first time in my life somebody's taught me something. I realized a few things which have always influenced my work. And I've learnt it here with you. Thank you very much for this. I'm sure I'll call you and I'll want to meet you again. Thank you very much you've let me develop.

This excerpt seems to confirm Julia's thoughtless, even missionary faith in the content and sense of coaching and training in the field of communication. However, we already know that she assessed very critically the behavior of many people working in this industry. This leads us to the conclusion that she saw fiction and deception in the way of "selling" knowledge of specific competences necessary in a free market economy, but its essence, functions, or usefulness have never been questioned by herquite the contrary, she treated them as an inalienable element of contemporary people. In this part of Julia's story, we find many symptomatic terms typical of the institutional pattern of action, which, on the one hand, seduces thanks to the opportunities offered, and, on the other hand, imposes the obligation to give it energy, mind, and soul (Schütze 2008a). In other words, her criticism and resentment never concerned "what" she sells, but only "how" it is sold; for example, not that the content of "knowledge" about stress management is a banal commercial "releasing" of common sense knowledge, but that it is conveyed by people with poor knowledge, but full of faith in themselves and their presentation (Goffman 1990). It is not possible to decide whether it is due to their carelessness or cynicism, but we should ask whether the contemporary (postmod- ern) world does not just sell one illusion by another illusion, appearance by appearance, or fraud by frauds (cf. Baudrillard 2005).

Again, what Julia sees and evaluates, and what she does not see and what she regards as obvious, makes us perceive her biography as an intense process of clashing values and attitudes socialized in childhood (and in the system of real socialism) with neoliberal virtues (Czyżewski 2009a; Waniek 2016a; 2016b). Looking at it in this way, one may risk the statement that what was defined in the public discourse-recalling the words of Andrzej Piotrows$\mathrm{ki}-\mathrm{as}$ the abolition of anti-order and restoration of order, in individual life history (or certain areas of experience) could be perceived conversely: as a transition from values to anti-values. In the case discussed here, and in the narrator's opinion, it would be a transition from solid, deepened knowledge to theatrical ignorance cover, or, in other words, from a game that goes according to certain rules known to all participants, in which every player can use the instructions he needs. To sum up, in the course of biographical work during the interview, the narrator discovers that the knowledge and acquired life orientations in fact became counterproductive to the requirements of the contemporary complex world of work, which largely limited the possibility of giving personal meaning to her professional experience and became a life trap.

This issue is particularly visible in the coda, which is one of the key cognitive figures of autobiographical narrative interview, where the informant usually summarizes and evaluates the course of his/her own life history and tries to determine whether the 
decisions made by him/her and which follows the chosen development path were correct. Most often, it closes the biographical work, the key element of which is not only to think about the past, but also a prudent look into the future (cf. Schütze 1984; 2008a; 2008b). In Julia's case-what should be noted-this closure does not take place, and the coda looks like this:

The joy of having an own flat is incredible. You sit on the floor. When we moved in there was nothing there, only the bathroom, nothing else. You sit on the floor and you think: God, at last I've got the place I may come back to, where I can come and sit down. And I don't have to move every year. Change places, apply for students' hostel, wait to get the room, move from one room to another, you know. The good thing was we didn't have many belongings. We were moving constantly, so there were not many things left. We haven't bought a lot. We've got eight plates, we've got all the mugs as gifts. We use the cutlery used by the people who used to live here before us. (...). My parents say that for them my life seems to be very difficult. They can't understand it. They want to make our life easier, so my mum brings all the lamps and sheets, and she always brings some food. She says for her everything was easy. She graduated from school, went to work, in the meantime she got married, she got pregnant, started her studies, had a baby, then she had the second baby, she completed her studies, they started building the house. And, you know, everything was easy then. They had work and the feeling of safety. And when she hears what I tell her, that I don't have a job, that nobody will sign a permanent work contract with me, that everything I do is on the basis of a deal, I mean, now you do this and that and we'll pay you this much. Such a system promotes people who are self-confident about their skills and knowledge. In fact, not necessarily they really can do something, but they think they can, and that's enough. And they will earn more than those who are aware of their incompetence. If you know you're not an expert yet, you are in a worse position than a person who is unaware of his incompetence. Unaware incompetence is worth much more than aware in competence. You know, I mean, this conviction: I can do it I am able to do everything, why not? OK. That's it. Enough Isn't it too much. I've talked too long.

Bringing her story to an end, the narrator talks about stabilizing and emotionally positive experiences connected with having her own "place on earth" (the flat) being, in fact, the only factor stabilizing her unstable life situation. But, having in the head a "fresh" overall picture of her biographical experience, not so optimistic in all dimensions, the narrator must place an additional comment that breaks the coda. ${ }^{38}$ Interestingly, she evaluates her life looking at it from the outside-from the point of view of her parents, who (especially mother) compare their own biography (linear predictable career based on well-defined achieved identities) with their daughter's life history ("ragged" professional career simultaneously interweaving many

${ }^{38}$ An autobiographical recapitulation should end with a sequence that puts off the narrator's memories and leads him/ her to the "here and now wo the interview and then a closing statement, "and that would be all," usually occurs. However,
if his/her experiences were extremely difficult or painul if his/her experiences were extremely difficult or painful, mentative commentary (in which the biographical manage attempts to close his biographical work) appears (it is often extensive). In such a case, we talk about a split coda, which is an important interpretation indicator. It provides the empirical evidence that, firstly, one of the process structures in the narrator's whole life was the trajectory of suffering and secondly, that he/she either got over it and tries to presen
his/her own attempts to go through its dynamics theoretically hish practically, or -if the explanations, assessments, or justifications appearing in it have a chaotic, foggy, ambiguous character-revels inability to close the biographical work and thus is still strong in his/her current life situation suffering experience. paths of various temporary jobs, filled with uncertainty and anxiety caused by a vague identity). Let me note that this "mediated" reference to her whole life means that the narrator is not able to directly summarize and assess the course of her own biography-and thus carry out a (looking into the future) full biographical work. She would have to refer to problematic areas of her life and admit to the interviewer and, above all, to herself that she is unable to cope with difficulties in establishing and implementing future life plans in a cognitive and emotional sense and, therefore, she has been placed in a destabilizing situation of suspension (limbo). To say it in other words: Julia makes an effort to push back from herself the need to work on the destructive potential of unstable career, which determines and limits her decisions in the private sphere, since making the forced abandonment of motherhood plans the object of reflection could be too painful, and considering existing opportunities, would expose the overwhelming situation of the trap.

Finally, once again the concept of social worlds should be considered as an alternative to multi-jobbing and precarious work approach or to the discourse of late modernity prevailing in social sciences (e.g., Giddens 1991; Castells 1996, 1997; Beck 2005). It is worth looking at Julia's biography and trying to consider her life situation from the perspective of belonging to different social worlds, which are competing, conflicted (but demanding loyalty of those involved), have different sources of meaning, use different logics and the criteria of authenticity. In the contemporary complex world, as Schütze (2002) writes, the biographical horizon of the sense takes the form of bricolage, which can lead to many important problems resulting from discrepancies, contradictions, or mutual devaluation of meanings related thematically to fragmentary biographical orientations and lack of credibility of the general structure consisting of these fragmentary thematic orientations: which means it can lead to chaos in biographical work. He also adds that disputes about the authenticity of actions or moral standards, collisions of interests, constant processes of segmentation and budding, struggle for symbolic and material resources within the social world itself, as well as external disputes make them lose their approximate power and the function of making sense of an individual's biography.

\section{Conclusions}

Julia-a political scientist and sociologist has (unconsciously) become an expert orientated to producing disciplined-and even self-disciplining-subordinates (Scott 2001). Her work was about "producing" creative individuals capable of managing themselves and their time, controlling stress, working in a team, writing and evaluating projects. To put it briefly, being herself a product of the discourses of governmentality, she reproduced them and-thanks to her missionary activity (as a trainer running trainings and courses, but also as a university lecturer)-she contributed to their strengthening and development. However, she herself fell victim to this form of exercising power, whose external conditions, interweaved with the internal dynamics of her life, significantly began to limit further positive development of her life history. Many of Julia's experiences - as shown by the analysis of her autobiographical statement-bear 
the trajectory traits: being overwhelmed by many diverse professional duties, chronic instability and uncertainty of the current life situation, feeling of pressure from employers and dependence on their "goodwill," or finally the necessity of suspending her life plans (motherhood). Her education acquired at the expense of hard work, for which she paid with lack of acceptance (at least at the elementary school level) and many sacrifices, does not translate into the expected social status, prestige, or-last but not least-financial profit. The promise of stabilization becomes an illusion. The biographical scheme of the narrator's work is constantly being suspended, which leads her to abandoning biographical work-if she consciously takes it up it would be a threat the ominous truth could confirm, and that every year it becomes more and more complicated or even unrealistic. Biographical structures in the current life situation do not guarantee a fully positive development of the biography and are in fact a trap threatening the autonomous development of identity.

Let me return for a moment to the above-mentioned cases of Hanna and Inga, which allowed me to state that in the life of all three narrators, "there's the visible tension arising from the fact that they try to meet the partially mutually exclusive outside imperative requirements: on the one hand (often expressed explicite) parents' expectations and, on the other hand, the pressures of capitalist rationality. Both of these sources of external pressure seem to block the biographical search lines and limit the autonomy of action" (Waniek 2016a:121-122). Paradoxically, however, the family is not only a force that determines a specific line of biographical development, but also a kind of "safety valve" that allows the easing of the tensions resulting from the oppressive conditions of functioning on the free market thanks to emotional and financial support. The minimal difference in Julia's experience is that while the institutional pattern of expectations directed Hanna and Inga's actions to the continuation of the economic and social position of the parents, in her case, it was about her improvement.

Finally, it is worth emphasizing that this one life history (of Julia) analyzed in reference to other minimally (mentioned here cases of Hanna and Inga) and maximally contrasting materials collected using the autobiographical narrative interview method as part of the "Transformation..." project showed multidimensionality and multilevelness of systemic transformations in an experience of an individual. They deny the common schematic and stereotyping distinction between "losers" and "winners" of the transformation, which entails discrediting of those who-in the conditions of "governing through freedom"-have not become enterprising enough to face the necessity of "taking life into their own hands." And as Ulrich Bröckling (2016:5) says: "Forcing people to develop their own individuality also means that ultimately they are to blame for their failures." The life history of Julia, however, shows a certain, not included in this dominant typology-and yet not that rare-modality of the dynamics of experience basing on the maximum use of biographical potential of an individual by the neoliberal labor market in its Polish version. This becomes possible due to the strong alluring embedded mechanisms that obscure (or expose it only to economic logic) other areas of the individual's life, as well as thanks to the commonly promoted and accepted, by virtue of taken for granted, necessity for empowerment.

Transferring our analysis to a higher degree of generality, it is worth referring to the considerations of Magdalena Nowicka (2014:239) on the Eastern European variant of postcolonialism, in which she emphasizes that those who do not accept a vision of emancipation embracing being an efficient, creative, reflective, creatively developing individual "are brutally excluded by theorists." At the same time, she refers to the words of Manuel Castells (2013:300), who states in an impertinent tone:

Changes are not automatic. They result from the will of social actors, as guided by their emotional and cognitive capacities in their interaction with each other and with their environment. Not all individuals are involved in the process of social change, but throughout history there are people who do, thus becoming social actors. The others are free-riders as the theory would put it. Or, in my own terminology, selfish parasites of history-making.

Further, Nowicka writes that Polish reflection (including the sociological one) "reveals the elitism of post-colonial emancipation" contrasting it with the post-Soviet mentality of the "non-subject" mass and thus "divides society into winners and losers, and ultimately into rational, adaptable ones and inept, unable to adapt numpties" (Buchowski 2008:101 as cited in Nowicka 2014:243). At this point, we can ask a question, how to qualify properly the case of Julia and what the elite did for these masses and could they do anything differently?
One solution would be a look at their actions through the prism of Fritz Schütze's idea of a liaison work concept inspired by the legacy of Everett Hughes (1972:303 and on)-one of the classics of the Chicago School. It involves the transition of differences in language-conditioned cultural codas (understood as the resources of interpretation that enable defining and giving meaning to the world of life) with simultaneous explanation of various points of view of interaction partners or different realities (cf. Czyżewski 2005:348). Marek Czyżewski distinguished three types of intermediary work in public discourse (2005:356-385; 2006:130-132): hegemonic, symmetrical, and asymmetrical. As it seems in the transition between the socialist social formation and the neo-liberal model of capitalism, the symbolic elites took up its hegemonic variant, that is, one that did not take into account other points of view ("of non-subjective" mass) and either simply ignored them or-defining them as unwise, wrong, distorted, or immersed in the mental legacy of communism-granted themselves the right to lecture and rebuke a "rebellious ward," reluctant to "do up modernizing backwardness" in reference to Europe (cf. Piotrowski 2005:338).

As a result, as Sergiusz Kowalski (1997:295) wrote, the process of decomposition of the former communist order was spreading: "it was the work of the elite, in which the masses had little to say, and even less to do." And yet it would be possible to introduce a modality that would take into consideration the other party's perspective on equal terms and take into account its hierarchy of validity (symmetrical variant) and even one that (in a special situation of suffering) would be based on pa- 
tient listening to the voice of an "ordinary citizen" (asymmetrical variant). At this point, once again, it is worth asking a question about the alleged guilt:

\section{References}

Baudrillard, Jean. 2005. Simulacra and Simulation. Michigan: The University of Michigan Press.

Beck, Ulrich. 2005. Power in the Global Age: A New Global Political Economy. Cambridge: Polity Press.

Bernstein, Basil. 1971. Class, Codes and Control, Vol. 3: Towards a Theory of Educational Transmission. London: Routledge \& Kegan Paul.

Bernstein, Basil. 1996. Pedagogy Symbolic Control and Identity. Theory, Research, Critique. London: Taylor and Francis.

Bogołębski, Tomasz. 2014. "Coaching w optyce rządnomyślności - próba krytycznej analizy zjawiska." Pp. 173-196 in Dyskurs elit symbolicznych. Próba diagnozy, edited by M. Czyżewski et al. Warsaw: Wydawanictwo Akadmickie SEDNO.

Bokszański, Zbigniew, Andrzej Piotrowski, and Marek Ziółkowski. 1977. Socjologia jezzka. Warsaw: Wiedza Powszechna.

Bourdieu, Pierre. 1986. “The Forms of Social Capital.” Pp. 241258 in Handbook of Theory and Research for the Sociology of The Forms of Capital, edited by J. Richardson. New York: Greenwood.

Bourdieu, Pierre and Jean-Claude Passeron. 1977. Reproduction in Education Society and Culture. London: Sage Publications.

Bröckling, Ulrich. 2016. The Entrepreneurial Self. Fabricating a New Type of Subject. London: Sage.

Burski, Jacek. 2016. “Klasa średnia a perspektywa biograficzna. Empiryczne studium przypadku." Przegląd Socjologii Jakościowej 12(2):78-93. are really "ordinary citizens" or intellectual and political elites to blame or whether the guilt lies somewhere else.

Castells, Manuel. 1996. The Rise of the Network Society, The Information Age. Economy, Society and Culture, Vol. I. Cambridge, Oxford: Blackwell.

Castells, Manuel. 1997. The Power of Identity. The Information Age: Economy, Society and Culture, Vol. II. Cambridge, Oxford: Blackwell.

Castells, Manuel. 2013. Communication Power. Oxford: Oxford University Press.

Clarke, Adele. 1991. "Social Worlds/Arenas Theory." Pp. 9-158 in Social Organization and Social Structure: Essays in Honour of Anselm Strauss, edited by D. R. Maines. New York: Aldine de Gruyter.

Czyżewski, Marek. 2005. Öffentliche Kommunikation und Rechtsextremismus. Lodz: Wydawnictwo Uniwersytetu Łódzkiego.

Czyżewski, Marek. 2006. "Dyskursy pro- i antyeuropejskie. Polaryzacja i 'praca pośrednicząca.' Zarys problematyki badawczej." Pp. 117-135 in Europa w polskich dyskursach, edited by A. Horolets. Torun: Wydawnictwo Adam Marszałek.

Czyżewski, Marek. 2009a. "Między panoptyzmem a 'rządomyślnością - uwagi o kulturze naszych czasów." Kultura Wspótczesna 2:83-95.

Czyżewski, Marek. 2009b. “Działania 'neopozorne.' Uwagi na temat przeobrażeń komunikowania publicznego i życia naukowego publicznego." Przeglad Socjologiczny 1:9-31.

Czyżewski, Marek. 2012a. "Dyskursy tożsamościowe w nauce i życiu społecznym: odmiany, własności, funkcje." Pp. 101120 in Tożsamość, nowoczesność, stereotypy. Księga Jubileuszowa poświęcona Profesorowi Zbigniezwowi Bokszańskiemu, edited by R. Dopierała and K. Kaźmierska. Cracow: Nomos.

Czyżewski, Marek. 2012b. “Wiedza specjalistyczna i praktyka społeczna - przemiany i pułapki." Pp. 71-93 in Kontrowersje dyskursywne. Między wiedza specjalistyczna a praktyka społeczna, edited by A. Jabłoński, J. Szymczyk, and M. Zemło. Lublin: Wydawnictwo KUL.

Czyżewski, Marek. 2013. “Socjologia interpretatywna i metoda biograficzna: przemiana funkcii, antyesencjalistyczne watpliwości oraz sprawa krytyki." Przeglad Socjologii Jakościowej 9(4):14-27.

Czyżewski, Marek, Sergiusz Kowalski, and Andrzej Piotrowski. 1997. Rytualny Chaos. Studium dyskursu publicznego. Cracow: Aureus.

Czyżewski, Marek et al. 2014. Dyskurs elit symbolicznych. Próba diagnozy. Warsaw: Wydawnictwo Sedno.

Dopierała, Renata. 2017. “Minimalism - a New Mode of Consumption." Przeglad Socjologiczny 4(66):67-83.

Durkheim, Emile. 1952. Suicide: A Study in Sociology. London: Routledge \& Kegan.

Foucault, Michael. 2008. The Birth of Biopolitics. Hampshire: Palgrave MacMillan.

Garfinkel, Harold. 2002. Studies in Ethnomethodology. Cambridge: Polity Press.

Gergen, Kenneth J. 2000. The Saturated Self: Dilemmas of Identity in Contemporary Life. New York: Basic Books.

Giddens, Anthony. 1991. Modernity and Self-Identity: Self and Society in the Late Modern Age. Stanford: Stanford University Press.

Goffman, Erving. 1955. “On Face-Work: An Analysis of Ritual Elements in Social Interaction." Psychiatry: Interpersonal and Biographical Processes 18(3):213-231.

Goffman, Erving. 1986. Stigma. Notes on the Management of Spoiled Identity. London: Touchstone Book.
Goffman, Erving. 1990. The Presentation of Self in Everyday Life. London: Penguin Books.

Hughes, Everett C. 1972. “The Linguistic Division of Labor in Industrial and Urban Societies." Pp. 296-309 in Advances in the Sociology of Language, edited by J. A. Fishman. The Hague, Paris: Mouton.

Kaźmierska, Kaja. 2016. “Wywiad narracyjny - technika i pojecia analityczne." Pp. 61-72 in Biografia i wojna, a tożsamość narodowa, edited by R. Dopierała and K. Waniek. Lodz: Wydawnictwo Uniwersytetu Łódzkiego.

Kaźmierska, Kaja and Fritz Schütze. 2013. “Wykorzystanie autobiograficznego wywiadu narracyjnego $w$ badaniach nad konstruowaniem obrazu przeszłości w biografii. Na przykładzie socjologicznego porównania narracji na temat życia w PRL-u i NRD." Przeglad Socjologii Jakościowej 9(4):122-139.

Kaźmierska, Kaja, Katarzyna Waniek, and Agata Zysiak. 2015. Opowiedzieć Uniwersytet. Eódź akademicka w biografiach wpisanych w losy Uniwersytetu Łódzkiego. Lodz: Wydawnictwo Uniwersytetu Łódzkiego.

Kowalski, Sergiusz. 1997. “Prawo moralne i rzady prawa. Czy wolność można wynegocjować?" Pp. 293-323 in Rytualny Chaos. Studium dyskursu publicznego, edited by M. Czyżewski, S. Kowalski, and A. Piotrowski. Cracow: Aureus.

Krzemiński, Ireneusz and Jacek Raciborski. 2010. Oswajanie wielkiej zmiany. Warsaw: Wydawnictwo IFiS PAN.

Leder, Andrzej. 2014. Prześniona rewolucja. Ćwiczenia z logiki historycznej. Warsaw: Wydawnictwo Krytyki Politycznej.

Marciniak, Mieczysław. 2016. “Pozytywne doświadczenia biograficzne w kontekście okupaciji: oportunizm i opór.” Pp. 191217 in Biografia $i$ wojna, edited by R. Dopierała and K. Waniek. Lodz: Wydawnictwo Uniwersytetu Łódzkiego.

Matysiak, Anna. 2009. “Employment First, Then Childbearing: Women's Strategy in Post-Socialist Poland." Population Studies: A Journal of Demography 3(63):253-276.

Mead, George H. 1934. Mind, Self and Society. Chicago: University of Chicago Press. 
Mrozowicki, Adam. 2016. “Normalisation of Precariousness? Biographical Experiences of Young Workers in the Flexible Forms of Employment in Poland." Przeglad Socjologii Jakościowej 12(2):94-112

Mrozowicki, Adam. 2017. “Od proletariatu do prekariatu? Doświadczenie klasy w biografiach robotników i młodych pracowników sprekaryzowanych w Polsce." Pp. 41-59 in Klasy w Polsce. Teorie, dyskusje, badania, konteksty, edited by M. Gdula and M. Sutowski. Warsaw: Instytut Studiów Zaawansowanych.

Nowicka, Magdalena. 2014. “Socjologia krytyczna a obietnica emancypacji." Stan Rzeczy 1(6):235-254.

Piotrowski, Andrzej. 1997. “Lẹk przed Europa." Pp. 324-337 in Rytualny chaos. Studium dyskursu publicznego, edited by M. Czyżewski, S. Kowalski, and A. Piotrowski. Cracow: Wydawnictwo Aureus.

Piotrowski, Andrzej. 2005. “Proces kształtowanie tożsamości narodowej w dyskursie potocznym i publicznym." Pp. 327-340 in Kregi integracji i rodzaje tożsamości. Polska. Europa. Świat, edited by W. Wesołowski and J. Włodarek: Warsaw: Scholar.

Prawda, Marek. 1989. "Biograficzne odtwarzanie rzeczywistości. O koncepcji badań biograficznych Fritza Schütze." Studia Socjologiczne 4:81-98

Riemann, Gerhard and Fritz Schütze. 1991. "Trajectory' as a Basic Concept for Analysing Suffering and Disorderly Social Processes." Pp. 333-357 in Social Organization and Social structure. Essays in Honour of Anselm Strauss, edited by D. R. Maines. New York: Aldine de Gruyter.

Riesman, David. 1989. The Lonely Crowd: A Study of the Changing American Character. London: Yale University Press.

Rose, Nicolas. 1998. Inventing Our Selves. Cambridge: Cambridge University Press.

Rose, Nicolas. 1999. Powers of Freedom. Cambridge: Cambridge University Press.

Rychard, Andrzej and Michał Federowicz. 1993. Spoteczeństwo w transformacii. Warsaw: Wydawnictwo IFiS PAN.
Schütze, Fritz. 1981. “Prozeßstrukturen des Lebensablaufs.” Pp. 67-156 in Biographie in handlungswissenschaftlicher Perspektive, edited by J. Matthes. Nürnberg: Verlag der Nürnberger Forschungsvereinigung.

Schütze, Fritz. 1983. "Biographieforschung und narratives Interview." Neue Praxis. Kritische Zeitschrift für Sozialarbeit und So zialpädagogik 13:283-293.

Schütze, Fritz. 1984. "Kognitiven Figuren des autobiographischen Stegreiferzälens." Pp. 78-117 in Biographie und Sozial Wirklichkeit:neue Beiträge und Forschungsperspektiven, edited by M. Kohli and R. Günther. Stuttgart: Metzlersche Verlagsbuchhandlung.

Schütze, Fritz. 2002. "Das Konzept der sozialen Welt im symbolischen Interaktionismus und die Wis-sensorganisation in modernen Komplexgesellschaften." Pp. 57-83 in Soziale Welten und kommunicative Stile. Festschrift für Werner Kallmeyer zum 60. Geburstag, edited by I. Keim and W. Schütte. Tübingen: Günter Narr Verlag.

Schütze, Fritz. 2008a. "Biography Analysis on the Empirica Base of Autobiographical Narratives: How to Analyse Autobiographical Narrative Interviews - Part One." European Studies on Inequalities and Social Cohesion 1-2:243-297.

Schütze, Fritz. 2008b. “Biography Analysis on the Empirica Base of Autobiographical Narratives: How to Analyse Autobiographical Narrative Interviews - Part Two." European Studies on Inequalities and Social Cohesion 3-4:5-77.

Schütze, Fritz. 2012. "Trajektorie cierpienia jako przedmio badań socjologii interpretatywnej." Pp. 414-458 in Metoda biograficzna w socjologii. Antologia tekstów, edited by K. Kaźmierska. Cracow: Nomos.

Schütze, Fritz and Anja Schröder-Wildhagen. 2012. “Europea Mental Space and Its Biographical Relevance." Pp. 255-278 in The Evolution of European Identities. Biographical Approaches, edited by R. Miller and G. Gray. Houndmills, Basingstoke, Hampshire: Palgrave MacMillan.

Schütze, Fritz et al. 2012. "Discoverers in European Mental Space: The Biographical Experiences of Participants in Europe- an Civil Society Organizations." Pp. 150-169 in The Evolution of European Identities. Biographical Approaches, edited by R. Miller and G. Gray. Houndmills, Basingstoke, Hampshire: Palgrave MacMillan.

Scott, John. 2001. Power. Cambridge: Polity Press.

Sennett, Richard. 1998. The Corrosions of Character. The Personal Consequences of Work in the New Capitalism. London: W.W. Norton \& Company

Shibutani, Tamotsu. 1955. “Reference Groups and Perspectives." American Journal of Sociology 60(6):562-569.

Sowa, Jan. 2010. "Prekariat - globalny proletariat w epoce pracy niematerialnej" Pp. 100-131 in Robotnicy opuszczaja miejsca pracy, edited by J. Sokołowska. Lodz: Muzeum Sztuki.

Stachowiak, Jerzy. 2013. "Pedagogizacja medialna i wzór 'przedsiębiorcy samego siebie."' Societas/Communitas 2:141-

Standing, Guy. 2011. The Precariat. The New Dangerous Class. London: Bloomsbury Academic.

Strauss, Anselm L. 1969. “Transforming of Identity.” Pp. 89-118 in Mirrors and Masks, by A. L. Strauss. San Francisco: The Sociology Press.

Strauss, Anselm L. 1978. “A Social World Perspective." Pp. 119128 in Studies in Symbolic Interaction, Vol. 1, edited by N. K. Denzin. Greenwich: JAI Press.

Strauss, Anselm L. 1982. "Social Worlds and Legitimation Process." Pp. 171-190 in Studies in Symbolic Interaction, Vol. 4, edited by N. K. Denzin. Greenwich: JAI Press.

Strauss, Anselm L. 1984. "Social Worlds and Their Segmentation Processes." Pp. 123-139 in Studies in Symbolic Interaction Vol. 5, edited by N. K. Denzin. Greenwich: JAI Press.

Strauss, Anselm L. 1993. "Social Words and Society." Pp. 209224 in Continual Permutations of Action, edited by A. L. Strauss. New York Aldine de Gruyter.

Szarfenberg, Ryszard. 2016. Prekarność, prekaryjność, prekariat - krótkie worrowadzenie. Retrieved September 27, 2019 (http:// rszarf.ips.uw.edu.pl/pdf/prekariat3.5.pdf)

Thomas, William I. 1969. The Unjusted Girl: With Cases and Standpoints for Behaviour Analysis. New York: Patterson Smith.

Waniek, Katarzyna. 2016a. "Potencjały bezładu i cierpieni w biografiach młodych kobiet wchodzących w świat sztuk i medycyny." Przeglad Socjologii Jakościowej 12(2):114-144.

Waniek, Katarzyna. 2016b. “Paradoxes of Liaison Work in Individual Experiences and Their Socio-Biographical Implications." Przeglad Socjologiczny LXV (65):9-32.

Wygnańska, Joanna. 2016. “Doświadczenie biograficzne życia w dwóch kulturach. Studium biograficzne przypadku." Przegląd Socjologii Jakościowej 12(2):168-190.

Zahorska, Marta. 2009. "Sukcesy i porażki reformy edukacii." Przeglad Socjologiczny 3(58):119-142.

Zarycki, Tomasz. 2009. "Kapitał kulturowy - założenia i perspektywy zastosowań teorii Pierre'a Bourdieu." Psychologin Społeczna 4 1-2(10):12-25.

Ziołłkowski, Marek. 2015. Teoria socjologiczna a transformacja spoteczeństwa polskiego. Warsaw: Scholar. liberal Reality." Qualitative Sociology Review 15(4):164-193. Retrieved Month, Year (http://www.qualitativesociologyreview.org/ ENG/archive_eng.php). DOI: http://dx.doi.org/10.18778/1733-8077.15.4.08 